\title{
GLOBALISATION AND THE CHANGING PARADIGM OF TRADE IN SERVICES
}

\section{P. A. Mathew, * Gerard Rassendren*}

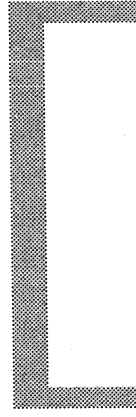

\section{Abstract}

Globalisation involves increasing interaction or integration of economic systems across the world through trade, capital and technology flows. So cross border exchanges has led to outlocating of investment and production. In this background this paper traces the trends of business process outsourcing, especially IT enabled services (ITES), in the country.]

"It is not from the benevolence of the butcher, the brewer, or the baker that we expect our dinner, but from their regard to their own interest."

Adam Smith, The Wealth of Nations (1776)

Globalisation has often been referred to an economic phenomenon involving the increasing interaction or integration of national economic systems through the growth in international trade and international capital flows. These imply elimination of domestic policy restraints and consequent reduction of the role of the nation state governance. This presupposes a rapid increase in cross-border social, cultural and technological exchange. It also presents itself as a phenomenon, which is, lived globally. It has become consequential by virtue of its institutional force within

* Lecturers, Dept. of Management Studies, Christ College, Banglore 
the state system and from there it reaches out to subject populations. Its major impact is effected through the worldwide process of restructuring of state and economies, bringing diverse populations and regions into the realm of a common dynamic. It is a qualitative extension of commodity relations.

In many ways, globalisation could be considered a paradigmatic shift. A globalising world is complex at many levels, developing within an already complex social, economic and political context. Many and varied dimensions of convergence and divergence can and do exist. It can be a harbinger of a new set up in which, there are overlapping and competing authorities, multiple loyalties and identities, prismatic notions of 'space and belief.' Most often globalisation creates an image of homogenisation. However real difference does persist and is often emphasized as a conscious choice in the global world economy. It is a market process driven by changing modes of competition and it compresses time and space aspects of social relations.

\section{Transnational mode of production and trade}

Globalisation is boundary broadening, which allows people, goods, information, norms, practices and institutions to move about in a free manner despite boundaries. Increased flexibility of technological tools is part of the global process - the diffusion of technology implies that the process of globalization places a premium on information and knowledge related activities. In a shrinking world, with increasing interdependent economies and communication technologies making a quantum jump, globalising dynamics are bound to prevail. Thus there is mushrooming of facilities, interests and markets through which a potential for worldwide spread can be realised. This leads to transnational modes of production and trade engendered by large organisations operating in more than one nation - state.

The process of 'internationalization of production', that is seeing the national lines of production in international terms, is one of the major changes in investment strategy. Technological advances made possible the fragmentation of the production process in various locations around the globe. In this way corporations could effectively utilize the low wage jurisdiction in developing countries, by setting up labour intensive activities and increasing the volumes and profit margin. This was essential to survive in a highly competitive environment. Advances in transportation and communication technologies meant that it is possible to transmit information to other locations and decision to invest there was not exactly based on serving that market alone even if it is the home market. 
Another outcome of this process is fragmentation of research and development activities in the case of knowledge intensive industries. There is also collaborative research amongst the competing firms to reduce the costs of research and development. This process has limited the capacity of any individual country to satisfy the investment of multinational firms.

Relaxation of restrictions on international flows lead to the importance of telecommunication services as an essential infrastructural input for accelerated economic growth. It was one of the pivots on which policy makers in developing countries approached the globalisation paradigm. The objective was to bring the benefits of communications to the communities and also serve the new policy objective of improving the global competitiveness of the economies to stimulate and attract foreign direct investments (FDI).

'Internationalization of production' has led to the internationalization of service industries. Service industries include a gamut of activities from banking, finance, telecommunications, entertainment, education etc. This sector dominates the economic life in terms of number of people employed and the contribution to Gross National Product (GNP). The internationalization of service industry brings with it the pressure to liberalize the market as well as the to incorporate services into new regional and international trading arrangements.

\section{International trade in services and its changing dimensions}

"--.- A service maybe defined as the change in the condition of a person, or of a good belonging to some economic unit, which is brought about as a result of the activity of some other economic unit, with the prior agreement of the former person or economic unit." The international trade in services can be divided into four categories: (a) those in which the producer moves to the consumer; (b) those in which the consumer moves to the producer; (c) those in which either the producer or the consumer moves to the other and (d) those in which neither the consumer nor the producer move to each other. Production, marketing and distribution of services have undergone tremendous changes in the past few decades. From being a largely decentralised sector dominated by small entrepreneurial units it has now grown in transnationalisation and standardisation.

The first category creates physical movement of labour and capital. Migration of people across nations in search of potential greener pastures has been an inseparable part of human history. Large-scale migration of Asians, Africans and Europeans 
were central in fashioning the world of the nineteenth century, its worldwide empires and the establishment of global economic and political dominance by people of European origin. Twentieth century migrations have been just as important, particularly in the creation of a post-colonial world order.

Developments in the world capitalist economy during the last two centuries have brought together far flung factors of production in the form of workers at economically advantageous locations - tropical plantations in the nineteenth century, oil fields in the middle east and cities of the developed world in the twentieth. The job profile of the migrants ranged from plantation coolies to artisans, factory workers in the nineteenth century to qualified professionals, traders and entrepreneurs. With the advancement in transportation facilities and the rising cost of manufacturing in the west, manufacturing facilities involving labour intensive areas got transferred to low cost countries, like China, India and rest of South East Asia.

In the era of globalisation, the role played by the fourth category of services where there is no need for physical proximity of neither the producer nor the consumer attains importance due to the advancements in telecommunications and information technology. It is in terms of data flows across borders. Of late these advancements have resulted in outsourcing of services and corporate support functions beyond geographical barriers. This has extended the logic of labour outsourcing to the other extreme. As a result it depends on technical progress and economies of scale.

The expanse of connectivity is so wide that geographical distance is of no relevance at all but cost is the most important variable influencing business location decisions. Declining charges of telecommunication infrastructure and declining unit cost of computing power increased opportunities for business to outsource non-competency areas. This process accelerated in creating a new form of commercial endeavor in the form of Business Process Outsourcing (BPO).

\section{The business of Business Process Outsourcing}

Business process outsourcing has been emerging as a key business opportunity for the export driven information technology (IT) software and services segment. The market consists of human intensive services delivered over telecommunication networks or the Internet to several businesses. The chief propellant for the growth of the BPO market is the introspection of transnational companies over their operations so as to identify their core competencies and focus on them alone. All other internally provided services which are not necessarily part of the core competencies 
but are indispensable for market survival, eventually become a candidate for being supplied by an external provider. This decision making process often includes an evaluation of the cost of owning technology along with its associated costs, that are not core to the enterprise. This increases the willingness to outsource non-core yet critical processes such as claims administration, human resource services and payment services. Other drivers are improvements in quality of service, process consolidation and reduction in cost of capital expenditure. All of these reduce transaction and process costs that free up precious capital that can then be applied to more strategic initiatives.

\section{Indian scenario}

India has a large base of BPO companies that are bagging prestigious service projects from leading global organizations. One third of the fortune 500 companies are shiffing their back-office operations to India. Despite world wide trade recession, Indian companies providing these services have shown high growth rates.

According to the recent Nasscom - McKinsey study the BPO industry will employ 1.1 million people and earn $\$ 17$ billion by 2008 , which was soon revised to $\$ 24$ billion. As on 31 March 2003, the sector employed 1,71,000 professionals. It has $\$ 1$ billion invested in it, creating about 1,00,000 smart cubicles in 7.5 million sq. ft of space. And it generated revenues of $\$ 2.3$ billion in 2002-03. The segments within the BPO industry are back office operations, remote education, data search, market research and customer interaction services, sales support, complaint handling, technical queries, relationship and account management, lead generation and follow up, telemarketing and credit and billing problems. In India, customer care is the dominant segment both in terms of revenue and employment. However the segments with high margins are not customer oriented but are in banking, insurance, telecommunications, healthcare, human resources, retailing and hospitality sectors.

India turned out to be a favourite destination for various reasons. The cost factor is the primary reason. At the infrastructural level fall in the international private lease line rates has made long distance telephone calls cheaper. In just two years there has been a 110-point drop in the rates of international lease lines. At the labour front, for example, in India a call centre associate is available at Rs. 45 per hour while his American counterpart charges Rs. 550 per hour. This means availability of such labour at less than $10 \%$ of the cost in US resulting in windfall annual savings. With the vast pool of English speaking students graduating every year from educational institutions the labour supply for these kinds of jobs is plenty. 
This is further accentuated by incentives provided by the government.

\begin{tabular}{|c|c|c|c|c|c|}
\hline Criteria & Goals & $\begin{array}{c}\text { Minimum } \\
\text { service } \\
\text { levels }\end{array}$ & $\begin{array}{c}\text { After 1 } \\
\text { month of } \\
\text { taking calls }\end{array}$ & $\begin{array}{c}\text { After 2 } \\
\text { months of } \\
\text { taking calls }\end{array}$ & $\begin{array}{c}\text { After 3 } \\
\text { months of } \\
\text { taking calls }\end{array}$ \\
\hline $\begin{array}{c}\text { Number of } \\
\text { calls }\end{array}$ & Tracking & $\begin{array}{c}90 \% \text { of } \\
\text { lesser of }\end{array}$ & $90 \%$ & $90 \%$ & $90 \%$ \\
\hline $\begin{array}{c}\text { Abandon } \\
\text { rate }\end{array}$ & $\begin{array}{c}8.8 \% \\
\text { dropped }\end{array}$ & $\begin{array}{c}10 \% \\
\text { dropped }\end{array}$ & $9 \%$ & $7 \%$ & $7 \%$ \\
\hline $\begin{array}{c}\text { Maximum } \\
\text { queue time }\end{array}$ & $\begin{array}{c}110 \\
\text { seconds }\end{array}$ & $\begin{array}{c}120 \\
\text { seconds }\end{array}$ & $\begin{array}{c}\sim 120 \\
\text { seconds }\end{array}$ & $\begin{array}{c}\sim 120 \\
\text { seconds }\end{array}$ & $\begin{array}{c}\sim 120 \\
\text { seconds }\end{array}$ \\
\hline $\begin{array}{c}\text { On-time } \\
\text { reports }\end{array}$ & $100 \%$ & $98 \%$ & $100 \%$ & $100 \%$ & $100 \%$ \\
\hline $\begin{array}{c}\text { Call } \\
\text { monitoring } \\
\text { score }\end{array}$ & $\begin{array}{c}90 \% 3 \text { or } \\
\text { better }\end{array}$ & $\begin{array}{c}90 \% 2.5 \\
\text { or better }\end{array}$ & $\begin{array}{c}80 \% \text { above } \\
2.5\end{array}$ & $83 \%$ above & $90 \%$ above \\
\hline $\begin{array}{c}\text { Customer } \\
\text { satisfaction }\end{array}$ & $\begin{array}{c}90 \% \text { or } \\
\text { greater }\end{array}$ & $>=85 \%$ & $79 \%$ & $81 \%$ & $85 \%$ \\
\hline $\begin{array}{c}\text { First time } \\
\text { resolution } \\
\text { rate (FTR) }\end{array}$ & $\begin{array}{c}80 \% \text { or } \\
\text { greater }\end{array}$ & $70 \%$ & $73 \%$ & $75 \%$ & $80 \%$ \\
\hline $\begin{array}{c}\text { Invoice } \\
\text { accuracy }\end{array}$ & $100 \%$ & $100 \%$ & $100 \%$ & $100 \%$ & $100 \%$ \\
\hline
\end{tabular}

Further productivity and quality of services have also acted as catalyst in transnational companies shifting operations to India. According to a recent McKinsey study an operation that takes 20 minutes to process in a US facility is handled in India in just 8 seconds. This is further substantiated in the following table, which shows the service level parameters to be achieved and the level of achievement.

\section{Table: 1 Service Level Goals and Service Levels Achieved}

The above table shows the several service level criterias, the performance levels expected as goals and minimum service levels and what has been achieved by Indians in an BPO services solution provided for a client by Wipro technologies for inbound calls which is the chief component of customer care. The client being serviced is a large personal computer manufacturer in the US and is a Fortune 500 company. The table shows that all the goals and the minimum service level parameters were either achieved or exceeded but never went to a shortfall. According to available reports this level of productivity was achieved within 90 days of transferring the process to India. Further Wipro began providing these services to this client with a staff of 25 , which has increased to 700 and is, growing in size.

Although price as a factor acts as an incentive in terms of shifting operations to India it is also the quality standards offered by Indian service providers that makes 
India an apt destination for BPO work. For example when Wipro takes on a job it will operate for three months with the exact specifications and quality standards used by the parent company. Then it will redesign the process around its own quality standards with a guarantee that the quality will improve. One such improvement had generated revenues for one of its client of 1.2 million pounds. In this way the Indian opportunity lowers the ceiling on what is economical to do. This demonstrates the economic rationale of outsourcing mundane administrative activities of an enterprise and further offshoring them to a provider who can deliver cost savings cum higher productivity. It also releases in-house executive personnel of the client to be used for higher value-added work.

BPOs have transformed India's economic landscape in more ways than one. Not only has it brought revenues worth billions of dollars it has also provided jobs to educated unemployed spread over the country. India's huge pool of English speaking graduates is being trained to handle services like customer complaints, telemarketing and medical transcriptions. BPOs in future can evolve into a more specialised activity encompassing higher end value added jobs giving opportunities to graduates in specialised areas like science, finance, technology etc. In this way there will a rising demand for qualified professionals for providing customers with technical solutions to specific problems. This is in sharp contrast to the situation in the west where BPO businesses do not necessarily attract people of higher intelligence. Thus BPO businesses not only bring in revenue but also expand the career options for the vast pool of India's educated unemployed.

\section{Challenges and implications}

The reasons for outsourcing are various - attaining internal flexibility, access to advanced technology, obtaining outside expertise, maintaining competitive edge, improving service quality, achieving cost reductions and building shareholder value. The recent growth in outsourcing industry indicates that achieving cost reduction is the most dominant factor, which makes India a favourite destination. According to an ASSOCHAM study on business process outsourcing $80 \%$ of the respondents felt that they could attain significant cost reductions through outsourcing.

However if cost is the dominant criteria in terms of shifting operations to India it may not be too long before there is competition from other countries that can compete on costs. Countries like China, Philippines, Ukraine, Russia etc will erode India's comparative advantage of lower costs.

The other advantage that India possessed was the vast English speaking educated work force. Many other countries are gearing up to the opportunities available in 
this business. China, for example, has made English a compulsory at all levels of their education system. This means that a large segment of its population will speak English fluently in a decade. Also Philippines with $94 \%$ literacy rate has majority of its 90 million citizens being English speaking. Therefore India will have challenges to its dominant position with regards to the BPO industry.

Indian BPO industry is facing challenges as they climb the maturity curve. Some of the factors leading to its success in the past may not work in its favour, as the market becomes more competitive and cost conscious. The overdependence on voice based businesses which is the mainstay of BPO business currently could turn out to be its Achilles heel. $60 \%$ of the BPO business coming to India is voice related and it has the lowest margin in the business. Maintaining a healthy balance between voice and non-voice work is an essential prerequisite to survive in this competitive condition. But Indian companies are still stuck with voice-related businesses rather than graduating to more value added businesses like transactions processing, human resources and consultancy, which could fetch them better margins. Intense competition is driving down the prices to unviable levels. This cuts into the revenue of voice related businesses because their labour costs are higher than non-voice businesses.

In addition to this, increased attrition rates among employees has increased the overall cost of operations. The high attrition rates are caused by several factors. A key business strength of the BPO industry is employees working through the night which is a fallout of the difference in the time zones between the east and west. This actually turns to be a key human resources weakness as employees feel they cannot handle the timing due to the disruption to their personal lives. Employee's satisfaction surveys point to the fact of job stress ailments such as sleeping disorders, digestive system disorders and eyesight problems are widely prevalent. Most of the employees are less than thitty years old and so are in the early stages of their career with a tendency to shift jobs. Further the satisfaction levels of employee's decreases rapidly with time and with lowest among those with more than five years experience.

There is an inherent investment cost involved in this context. Individuals who join organisations in the BPO business undergo generic as well as job specific training which translates into expenditures for the enterprise. If a person does not contribute to the enterprise for a minimum time period these expenditures do not give any returns. Such staffing discontinuity negatively affects the pursuance of business goals.

Another factor, which could act as an impediment in the future growth of BPO business, is the lack of experience in dealing with large contracts extending beyond 
$\$ 100$ million. Ability to set up large operations quickly and preventing high attrition rates are crucial elements in bagging such big orders. Firms also need to consolidate their businesses with few clients and acquire more business from existing clients.

Indian BPO business also has to address the challenge of the entry of transnational $\mathrm{BPO}$ monoliths such as the $\$ 1.3$ billion Convergys Corp, $\$ 21.6$ billion EDS and $\$ 11.2$ billion CSC. All these corporations have made their entry into India considering the advantages of this location. The asset worth and turnover of these companies are more than India's entire BPO industry. Their Indian operations can offer the same advantages that Indian companies can provide. Their financial power can drive down prices, which will further endanger the position of Indian companies.

The proliferation of small BPO companies trying to acquire business through middlemen and provoking price reductions and undermining quality as well as profitability adds further danger to the Indian BPO industry. By this these small players are also prospective candidates for acquisition by big corporate monoliths.

The anti-outsourcing power lobby in the US consisting of a few senators and congressmen has supplemented to the furmoil in the industry. Legislations aimed at keeping jobs is pending in at least five states, that is New Jersey, Connecticut, Maryland, Missouri and Washington state. The bills employ a variety of methods, including blocking companies from using foreign workers on state contracts and requiring foreign $\mathrm{BPO}$ employees to identify where they are located. These legislations range from the Senate Bill 1349 (New Jersey) which specifically bars outsourcing to India by State enterprises to the Washington State Bill that lays down strict procedures to slow down the outsourcing work for any company, including private ones, in the state. The Washington Bill also defines layoffs, mass layoffs, relocations, terminations and also rechristens outsourcing work as 'relocation'.

There is also a proposed L-1 visa bill in the U.S. seeking to restrict the use of such visas by Indian companies. This will restrict the number of software professionals that can be sent by Indian software companies to carry on onsite work at client sites. As Indian BPO vendors move up the value chain and target new service lines like systems integration, packaging integration, package implementation, IT outsourcing and IT consulting, they need to operate on a offshore or onsite model. The proposed L-1 visa bill will severely hamper the growth potential in these segments.

The catalyst to this lobby is the sluggish growth of the US economy leading to $6 \%$ rate of unemployment, which is the highest in four years. Many of these unemployed people are well-educated white-collar workers who are more vocal and articulate 
of their grievances. According to a Forrester Research report 3.3 million of the 6 million US BPO jobs will be outsourced in the next decade. In some of the states in the US like Ohio, call centers are the main job providers. Exit of these would mean its populace moving over to more menial jobs. This scenario has been the rationale for tightening of visa regulations and several new planned enactments in state legislatures to prevent outsourcing.

\section{Concluding observations}

In the nineteenth century coolie labour in the plantations were considered menial to be performed by the colonialist. So they resorted to indentured labour to fill the labour shortage created by the official abolition of slavery and the demands of capital accumulation. Although the working conditions of indentured Labour were less enviable it was compensated by projecting their wage earning ability to be better than the labour which remained in the native land. Coincidentally in the globalised era transnationalisation of production and technology have brought about a similar paradigm without necessitating physical movement of labour. The nature of jobs being outsourced as third party provided BPO services are administrative, procedural and mundane. For example in IT services it is mainly data entry and conversion, in financial or human resource services it is payroll processing and not niche operations such as high-end healthcare services which require specialised skills. In other words the lower end tasks of business processes are predominantly outsourced to Indian BPO providers. Therefore just as abundant labour supply was capitalised upon by the colonialists to acquire plantation labour, the new world economic order functioning through transnationals are perpetuating the same process by giving the lower end jobs to developing countries. If the Indian BPO industry has to reverse this historical trend it must move up to more value added businesses and compete more aggressively on the quality front.

The entry of transnational BPO monoliths having financial power and business experience will lead to price wars that will take away the main attraction in the industry as in higher salaries and cornering of large contracts from other transnational clients. By this these companies not only benefit from low labour and infrastructural costs but also create reverse outflow of business earnings.

The transnational monoliths originate in the developed countries of the north. These governments of the north aggressively promote the process of elimination of entry barriers, parity of treatment to foreign companies and removal of restrictions in flow of data and trade espousing the cause of globlisation in developing countries. At the same time they commit trade distortions by imposing visa restrictions and introducing 
new legislation, which can hamper the free flow of goods and services across nations. It also means that these countries reaping the benefits of internationalisation of trade are indirectly converting comparative advantages into absolute advantages. This behaviour contradicts the fundamentals of globalisation ethics.

According to Adam Smith self-interest dominates economic activity in any society. More than two hundred years later during the era of globalisation which emphasises on the free flow of goods, services, capital and people, with tremendous leaps in technology, self-interest still dominates the economic arithmetic of any polity and society.

\section{Bibliography}

- Anthony Giddens, The Consequences of Modernity, (Stanford, Stanford University Press, 1990).

- ASSOCHAM Study on BPO by the Communications Convergence Committee, August 2002.

- ASSOCHAM Bulletin, (various issues).

- $\quad$ Agent on Call, Human Capital, February 2003.

- BPO Employee Satisfaction Survey 2003, Dataquest, September 30th 2003.

- Claire Turene and Sjolander, "The Rhetoric of Globalisation: What's in a wor(I)d?" International Journal, No. 51 (4), Autumn 1996.

- Diaspora to Transnational Networks: The Case of Indians in Canada, Occasional Paper - 7, Centre for the Study of Indian Diaspora, University of Hyderabad, Hyderabad, August 2003.

- Kalyan Banerii \& Tarjani Vakil, India Joining the World Economy, (New Delhi, Tata McGraw- Hill, 1995)

- Philip de Michael "Globalisation: Myths and Realities, Rural Society, vol.6, no.1, Spring 1996.

- T. P. Hill, 'On Goods and Services', Review of Income and Wealth, December 1977. 


\section{References}

1. Philip de Michael "Globalisation: Myths and Realities, Rural Society, vol.6, no.1, Spring 1996.

2. Anthony Giddens, The Consequences of Modernity, (Stanford, Stanford University Press, 1990) p.64.

3. Claire Turenne and Sjolander "The rhetoric of globalization: what's in a wor $(\|)$ d?" International Journal, No. 51(4), Autumn 1996, p. 604.

4. T.P. Hill, 'On Goods and Services', Review of Income and Wealth, December 1977

5. Deepak Nayyar, "International Trade in Services", in (eds), Kalyan Banerii \& Tarjani Vakil, India: Joining the World Economy, (New Delhi, Tata McGraw-Hill, 1995) p.7.

6. Business World, 4th August 2003, p. 29.

7. www.wiprospectramind.com

8. BPO Employee Satisfaction Survey 2003, Dataquest, September 30th, 2003, p. 12 - 18.

9. Agent On Call, Human Capital, February 2002, p 27.

10. ASSOCHAM Bulletin, July 2003, p 1.

11. Helplinelaw.com

12. Business World, 4th August 2003, p. 29. 